\title{
TOBACCO INVESTIGATIONS IN OHIO.
}

WASHINGTON : GOVERNMENT PRINTING OFFICE. 



\section{Historic, archived document}

Do not assume content reflects current scientific knowledge, policies, or practices. 



\section{U. S. DEPARTMENT OF AGRICULTURE.}

BUREAU OF SOILS-BULLETIN N0. 29. MILTON WHITNEY, Chief.

\section{TOBACCO INVESTIGATIONS IN OHIO.}

GEORGE T. McNeSS and GEORGE B. MASSEY.

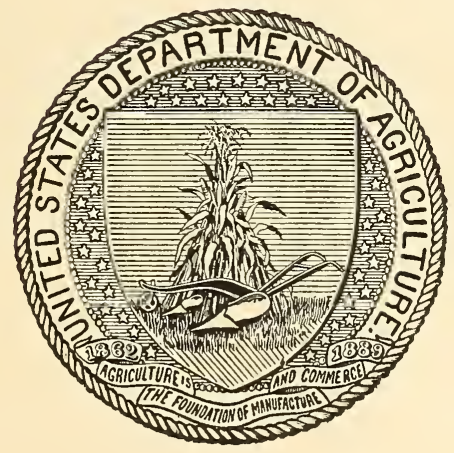

WASHINGTON:

GOVERNMENT PRINTING OFFICE.

1905 . 
BUREAU OF SOILS.

Miltox Whitsey, Chief of Bureau.

Albert G. Rice, Chief Clerk.

\section{SCIENTIFIC STAFF}

Lymax J. Briggs, in charge of Laboratory of Soil Physics.

Fraxk K. Camerox, in charge of Laboratory of Soil Chemistry.

FraNk D. GARDNER, in charge of Soil Management.

GEORGE T. MCNEss, in charge of Tobacco Investigations.

Clarexce W. Dorser, in charge of Alkali Land Reclamation.

George N. Coffer, in charge of Soil Survey.

ASSISTANTS IN TOBACCO INVESTIGATIONS.

WALTER M. Hissox.

George B. Massey.

J. B. Stewart.

LEWIS W. AYER.

HARRY Rich.
HeNRT WeINBerg.

IV. J. WOOD.

Отто OLsox.

R. S. Epley.

W. W. GreEN.

E. H. Mathewson. 


\section{LETTER OF TRANSMITTAL.}

\section{U. S. Departient of Agriculture, Bureau of Solls, Washington, D. C., June 15, 1905.}

SIR: I respectfully transmit herewith a report by Messrs. George T. McNess and George B. Massey on Tobacco Investigations in Ohio, including the growing of Cuban seed tobacco and the introduction of the bulk method of fermentation. I recommend that this report be published as Bulletin No. 29 of the Bureau of Soils. Respectfully,

Hon. Jayies WiLson,

Milton Wiritney, Chief of Bureau. Secretary of Agriculture. 



\section{CONTENTS.}

Introduction $=$ Page.

Climate _. . o _...

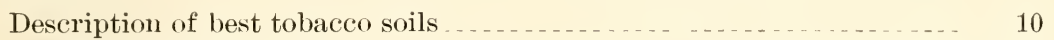

Miami gravelly loam . . . . .

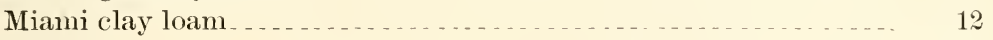

Types of leaf …

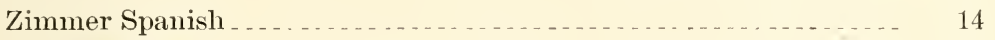

Ohio seed leaf _...

Little Dutch . . . . . . .

Cuban seed leaf ...

Growing of Cuban seed tobacco $\ldots \ldots \ldots$

Details of the work in $1904 \ldots \ldots \ldots$

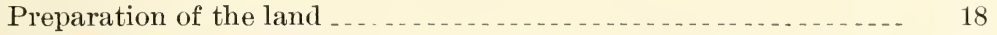

The seed bed . . . .

Transplanting _ _ . . . .

Cultivation _...

Topping and suckering _...

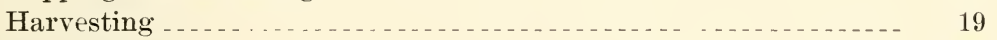

Barn curing . . .

Fermentation

Baling _.

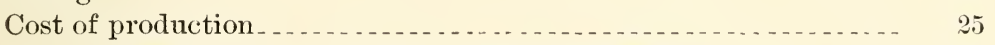

Sale of tobacco grown in 1902 and 1903 experiments _...

Introduction of bulk fermentation in Ohio _...

Des ription of various methods

Details of fermentation of leaf of different types _... 30

Relative cost of different methods of fermentation ........ 33

Cooperative work during three seasons _...

Letters from the trade 



\section{TOBACCO INVESTIGAT'IONS IN OHIO.}

\section{INTRODUCTION.}

The production of tobacco adapted to the different market demands has become a prominent factor in our agriculture. Of particular importance is the production of superior filler-leaf tobacco. The filler leaf of a cigar, above all things, must have a good flavor, good aroma, and good burn. It has long been recognized by the tobacco trade that the leaf grown on the strong, heavy soils found in the Miami Valley of Ohio makes the most desirable filler grown in this country. Although the leaf does not possess the mild aroma and fragrance of the Cuban tobacco, yet it has such desirable qualities that the culture of tobacco has become the principal industry of that part of Ohio.

The growing of cigar leaf in Ohio dates back to 1797 , when the early settlers grew small crops for their own consumption. About the year 1838 Mr. S. Pomeroy, of Suffield, Conn., moved to the valley, carrying with him some tobacco seed from his native place. He planted a small field in Miami Township, Montgomery County, and from this beginning the cultivation of tobacco gradually spread to the neighboring farms. The only tobacco, however, reported in the census of 1840 from the present Miami Valley district was 95 pounds, grown in Clark County.

The cultivation of tobacco was confined to Montgomery County until 1850, when some farmers in the neighborhood of Alpha, in Green County, began to grow it. In 1851 a small quantity was produced in Butler County, in Dicks Creek Valley, and within the next three or four years the cultivation extended successively into Warren, Preble, and Miami counties. Previously to 1850 a few patches were grown in several counties from Virginia seed for domestic use. The census for that year reported 2,500 pounds for Butler County, 1,460 pounds for Clinton County, 135 pounds for Champaign County, 7,132 pounds for Drake County, 2,500 pounds for Miami County, 50 pounds for Preble County, and 2,601 pounds for Warren County. Montgomery County for the same year reported 196,971 pounds, or 
about 500 cases, which shows that tobacco had become a staple in that district.

The crops grown in the Miami Valley in 1850 and 1851 amounted to about 2,000 cases, and in the succeeding year the production had risen to 4,000 cases, an increase of 100 per cent in a single year. All these crops were marketed in New York. That grown in 1850 brought from 9 to 10 cents a pound, but the crop of 1851 areraged only $4 \frac{1}{2}$ cents a pound.

The growing of tobacco on a commercial scale was first developed on the soils of the river bottoms. No effort was made to grow a fine quality of leaf, the main object being to produce a large vield. which was used mostly for binders and wrappers of cheap cigars.

With the change which came in the character of the leaf demanded by the dealers, these river bottom lands were given up to a large extent and the rolling uplands used for the growing of cigar fillers. Although improvements have been made in the selection of suitable soils and in the method of planting, the Ohio tobacco grower is still deficient in his knowledge of the curing of his crop. Great loss is experienced every year in damage from mold and pole rot. This is due to a great extent to the poor construction of the curing sheds and the lack of sufficient barn room at harvest time.

It was the object of the Bureau of Soils in making the experiments detailed in this report to prove to the tobacco grower and packer of the Miami Valley that an improved type, containing qualities similar to the tobacco grown in Cuba, could be grown on certain of their soils, and also that by improved methods of curing and fermentation the annual loss arising from mold and pole rot could be largely if not wholly overcome.

\section{CLIMIATE.}

The climate of southwestern Ohio is typical of a large part of the central interior region of the United States. There is a maximum range in temperature, between the coldest days in winter and the hottest in summer, of $115^{\circ} \mathrm{F}$., the difference between a minimum of $-15^{\circ} \mathrm{F}$. and a maximum of $100^{\circ} \mathrm{F}$.

The following table is compiled from the long-established records of the Weather Bureau station at Cincinnati. This station is not over 35 miles from the area surveyed in Montgomery County, and so may be taken as representing the general condition in the Miami Valley tobacco district. The figures presented in this table are normals computed on records extending over many years. The normals for each of the months of the growing season and for the entire year are shown. 
Climatological duta for sonthestern Ohio.

\begin{tabular}{|c|c|c|c|c|c|}
\hline Month. & $\begin{array}{c}\text { Mean } \\
\text { maximum } \\
\text { tempera- } \\
\text { ture. }\end{array}$ & $\begin{array}{c}\text { Mean } \\
\text { minimum } \\
\text { tempera- } \\
\text { ture. }\end{array}$ & $\begin{array}{l}\text { Mean } \\
\text { monthly } \\
\text { tempera- } \\
\text { ture. }\end{array}$ & $\begin{array}{l}\text { Average } \\
\text { monthly } \\
\text { rainfall. }\end{array}$ & $\begin{array}{c}\text { Mean } \\
\text { relative } \\
\text { humidity. }\end{array}$ \\
\hline April. . & $\begin{array}{r}\circ F . \\
633\end{array}$ & ${ }^{\circ} F$. & ${ }^{\circ} H^{\prime} \cdot{ }_{5 i}$ & $\begin{array}{r}\text { Inches. } \\
3.3\end{array}$ & Per cent. \\
\hline May . ........... & 74 & 57 & 65 & 4.0 & $6 ; 3$ \\
\hline June & 81 & 65 & 74 & 4.4 & (6) \\
\hline July & 86 & 69 & $\%$ & 3.9 & (65) \\
\hline August & 84 & 67 & 75 & 3.8 & 65 \\
\hline 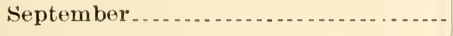 & 78 & $6:$ & 68 & 3.0 & 69 \\
\hline Annual. & 63.8 & 48.9 & 56 & a22. 4 & 69 \\
\hline
\end{tabular}

a Total for six months.

The following table shows the average monthly and annual temperature and the monthly and annual rainfall at Cincinnati and Dayton for the three years during which experiments in growing Cuban seed leaf tobacco have been carried on:

Monthly and annual temperature and precipitation.

\begin{tabular}{|c|c|c|c|c|c|c|c|c|c|c|c|c|}
\hline \multirow{3}{*}{ Month. } & \multicolumn{6}{|c|}{ Dayton. } & \multicolumn{6}{|c|}{ Cincinnati. } \\
\hline & \multicolumn{2}{|c|}{1902.} & \multicolumn{2}{|c|}{1903.} & \multicolumn{2}{|c|}{1904.} & \multicolumn{2}{|c|}{1902.} & \multicolumn{2}{|c|}{1903.} & \multicolumn{2}{|c|}{1904.} \\
\hline & $\begin{array}{l}\text { Tem- } \\
\text { pera- } \\
\text { ture. }\end{array}$ & $\begin{array}{l}\text { Pre- } \\
\text { cipita- } \\
\text { tion. }\end{array}$ & $\begin{array}{l}\text { Tem- } \\
\text { pera- } \\
\text { ture }\end{array}$ & $\begin{array}{l}\text { Pre- } \\
\text { cipita- } \\
\text { tion. }\end{array}$ & $\begin{array}{l}\text { Tem- } \\
\text { pera- } \\
\text { ture. }\end{array}$ & $\begin{array}{l}\text { Pre- } \\
\text { cipita- } \\
\text { tion. }\end{array}$ & $\begin{array}{l}\text { Tem- } \\
\text { pera- } \\
\text { ture. }\end{array}$ & $\begin{array}{l}\text { Pre- } \\
\text { cipita- } \\
\text { tion. }\end{array}$ & $\begin{array}{l}\text { Tem- } \\
\text { pera- } \\
\text { ture. }\end{array}$ & $\begin{array}{l}\text { Pre- } \\
\text { cipita- } \\
\text { tion. }\end{array}$ & $\begin{array}{l}\text { Tem- } \\
\text { pera- } \\
\text { ture. }\end{array}$ & $\begin{array}{l}\text { Pre- } \\
\text { cipita- } \\
\text { tion. }\end{array}$ \\
\hline & ${ }^{\circ} F$. & $I n$. & ${ }^{\circ} \mathrm{F}$. & In. & ${ }^{\circ} F$. & In. & ${ }^{\circ} F$. & In. & ${ }^{\circ} F$. & $I n$. & ${ }^{\circ} \mathrm{F}$. & $I n$ \\
\hline January - & 28.9 & 1.13 & 28.2 & 2.39 & 21.3 & 4.61 & 31.5 & 2.10 & 31.1 & 2.05 & 27.0 & 2.66 \\
\hline February. & 22.2 & .61 & 32.0 & 4.79 & 25.4 & 2.53 & 25.1 & .38 & 34.6 & 5.76 & 28.9 & 2.66 \\
\hline March ..... & 43.0 & 2.55 & 47.6 & 3. 69 & 41.8 & 7.90 & 44.8 & 1.47 & 49.7 & 4.97 & 44.2 & 8.17 \\
\hline April .. & 49.3 & 2.13 & 51.2 & 3.66 & 45.4 & 3.18 & 52.8 & 2.87 & 53.6 & 3.49 & 48.2 & 2.28 \\
\hline May .. & 65.4 & 2.39 & 65.2 & 4.66 & 61.6 & 4.05 & 67.6 & 5.54 & 67.4 & 3.83 & 64.2 & 3.70 \\
\hline June .... & 69.8 & 7.32 & 66.0 & 9.09 & 70.2 & 2.47 & 71.8 & 5.25 & 67.6 & 3.27 & 72.4 & 2.60 \\
\hline July ....... & 75.8 & 3.42 & 75.2 & 1.43 & 73.6 & 3.04 & 77.4 & 3.47 & $7 \pi .8$ & 2.31 & 75.5 & .80 \\
\hline August .... & 71.9 & .71 & 74.3 & 1.17 & 71.6 & $1.8 \pi$ & 74.3 & .65 & 74.9 & 2.75 & 75.0 & .41 \\
\hline September . . & 65.4 & 4.95 & 67.4 & .65 & 66.6 & 2.00 & 66.6 & 4.26 & 69.2 & 1.78 & 69.9 & 1.28 \\
\hline October ..... & 56.4 & 3.25 & 55.0 & 2.72 & 53.6 & 1.23 & 58.6 & 2.77 & 57.5 & 1.31 & 56.7 & .89 \\
\hline November . & 49.8 & 3.56 & 38.2 & 2.44 & 41.8 & .63 & 52.4 & 3.29 & 40.4 & 1.45 & 44.4 & .34 \\
\hline December .... & 30.6 & 3.95 & 25.8 & 2.00 & 29.3 & 4.16 & 33.0 & 5.25 & $2 \pi .6$ & 1.72 & 32.4 & 3.75 \\
\hline Annual & 52.4 & 35.97 & 52.2 & 38.69 & 50.2 & 37.67 & 54.7 & 37.30 & 54.3 & 34.69 & 53.2 & 29.54 \\
\hline
\end{tabular}

From the foregoing table it is seen that July and August are the hottest months and January and February are the coldest months in the year. The greatest precipitation takes place in May and June.

$3160-$ No. $29-05$ M- -2 
The following table gives the actual rainfall on the tobacco field near Germantown, and the dates on which precipitation occurred, during the growing of the experimental crop in 1904:

Rainfall at Germantown.

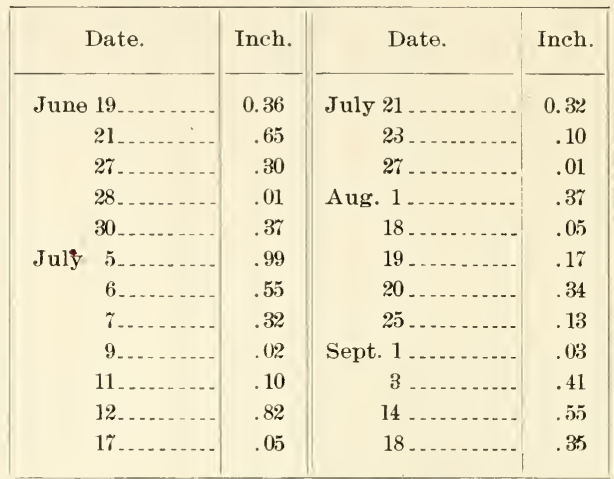

In 1904 the last killing frosts in spring occurred at Dayton, on May 16, and at Cincinnati, on April 25, while the first in the fall occurred on October 7 and 28, respectively, for the two stations. There was thus a growing season for tender plants ranging from 144 to 186 days.

DESCRIPTION OF BEST TOBACCO SOILS.

MIAMI GRAVELLY LOAM.

The two soils found most suitable for the cultivation of tobacco are the Miami gravelly loam and the Miami clay loam.

The Miami gravelly loam occupies large areas in the river valleys. This is generally known as the second bottom, and is considered the finest farming land in the valley. The principal areas are situated between the Great Miami and the Mad rivers, and a few miles south of Dayton, east of the Great Miami River, in Van Buren Township. There is also another large area in West Dayton, but it is mainly occupied by the city. In addition to these there are several other areas of a few square miles in extent. This formation may occur as a high first bottom, but generally as the second terrace above the river beds. These river bottoms. or. more properly speaking, terraces, are from 30 to 60 feet above the river level. When a number of successive terraces are found they rise from 5 to 15 feet, one above another. Rarely five distinct terraces may be counted, but the most common occurrence of this formation is, as stated, either as a high first terrace or a rolling terrace 10 to 15 feet above the areas of the Miami loam formation.

The soil is derived from the great mass of glacial débris deposited over the country by the ice, but this material has subsequently been 
modified considerably by the action of the streams which flow through the valley. These rivers and streams must have been greatly swollen during the closing period of the Glacial epoch when they received the waters from the melting masses of ice covering the comntry to the northward. The terraces certainly bear witness to the assorting and carrying power of these swollen rivers, for in every instance they are found to consist of beds of great thickness composed of well-rounded and nicely assorted gravel and sand. Although the terraces are composed largely of gravel, the soil carries more or less silt and clay. The soil may be described as a heavy, sticky, reddish-brown loam to a depth of 12 inches. This soil contains some sand, but there is sufficient clay to give it the properties of a heavy loam. Under the soil is found a stiff reddish-brown clay loam, quite similar to the subsoils of the clay uplands, but always containing a larger percentage of sharp angular quartz somewhat less than one-half inch in diameter. The subsoil as we go deeper contains more and more gravel, until at 30 feet it grades into a mass of well-rounded gravel. Exposures of 30 and even 40 feet of well-rounded stratified gravel underlying these soils were noticed in some of the old gravel pits above and below Dayton. These gravel beds insure perfect drainage conditions and render the soil warm and dry. On the surface there is a varying amount of well-rounded gravel from 2 to 5 inches in diameter. The quantity of gravel contained in the soil to a depth of 10 inches is seldom less than 15 per cent and rarely more than 40 per cent. Excessive quantities of gravel on the surface of the soil are found only in very limited areas. Often along the slopes from one terrace to another the gravel may be found coming to the surface in considerable quantities. Generally the gravel is nearer the surface in the large areas south of Dayton than it is in other extensive areas of this formation. None of the areas is subject to overflow from the rivers even during the highest floods.

The second bottoms were eagerly songht by the early settlers, for it was recognized that the soils were light, warm, and dry, and would produce twice as much as the cold, wet uplands. When discovered they are said to have been covered with a thick growth of sugar maple, black walnut, many kinds of oak, ash, hickory, mulberry, elm, locust, buckeye, basswood, sycamore, cherry, hackberry, gum, and beechtrees which denote a rich, productive soil. But little now remains of the once extensive forest, and only scattered groves are seen, which are mostly a growth of a few varieties of oak.

The Miami gravelly loam is always in demand, and some of the best-improved farms of the county are to be found on the slightly rolling terraces. It was on this soil that the early cultivation of tobacco received such an impetus, and for a long time it was consid- 
ered the finest tobacco land of the valley, but with the ever-changing demands of the trade it is not now so important as formerly, although many large fields of tobacco are grown each year on this type of soil.

The following table shows the texture of the interstitial material forming this soil:

Mechanical analyses of Miami gravelly loam.

\begin{tabular}{|c|c|c|c|c|c|c|c|c|c|}
\hline No. & Locality. & Description. & 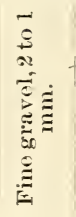 & 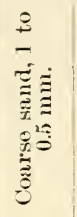 & 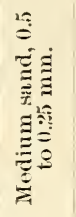 & 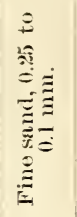 & 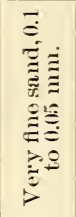 & 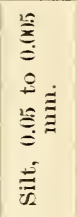 & 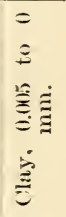 \\
\hline 50018 & North of Dayton ........ & 0 to 12 inches.... & $\begin{array}{r}\text { P. ct. } \\
5.51\end{array}$ & $\begin{array}{l}\text { P.ct. } \\
11.23\end{array}$ & $\begin{array}{r}\text { P. ct. } \\
9.36\end{array}$ & $\begin{array}{l}\text { P. ct. } \\
17.66\end{array}$ & $\begin{array}{l}\text { P. ct. } \\
15.58\end{array}$ & $\begin{array}{l}\text { P. ct. } \\
25.59\end{array}$ & $\begin{array}{l}\text { P.ct. } \\
12.95\end{array}$ \\
\hline 5009 & Subsoil of $5008 \ldots \ldots \ldots$ & 12 to 24 inches.... & $1 \pi .64$ & 14.60 & 10.06 & 9.90 & 6.19 & 13.00 & 26.53 \\
\hline
\end{tabular}

MIAII CLAY LOAM.

The Miami clay loam covers fully four times as large an area in Montgomery County as all the other formations combined. Frequently the roads extend a long distance through this type without a change in the character of the soil other than the slight changes depending upon the rarying drainage conditions of the different fields. There are large areas in the northern part of the county that are the exact counterpart of equally large areas in the extreme southeastern and southwestern portions of the county.

The surface features of this soil vary greatly in the different sections of the county. In the northern and central parts the topography is that of a broad, level, or gently rolling plain. In the other sections the surface is hilly and broken, although there are frequent interstream areas which are comparatively lerel for a considerable distance. In the level areas the fields are apt to be poorly drained, and formerly this was much more generally the case, but the opening of the large ditches and the improvement of the fields by underground drains have put the lands in excellent condition. so that they are no longer spoken of as cold, wet uplands. In the more hilly areas the drainage is well established, and artificial drainage is unnecessary. Where the upland borders the valleys there is often a steep scarp of from 80 to 120 feet. but where the valley gradually merges into the uplands a distance of several miles may be traversed before the general level of the upland is reached.

This soil is the weathered product of the heterogeneous mass of ground-up rocks left upon the surface in glacial times. This deposit of glacial débris varies from 2 feet to more than 100 feet in thick- 
ness, depending upon the inequalities of the surface before the material was deposited.

The soil of the Miami clay loam is a light loan containing a relatively high proportion of silt. It is a remarkably uniform soil, whether found on the steep hillside or on the more level uplands. It has a light yellowish-brown color when newly plowed or when moistened by recent rains. When not stirred for several weeks in a hot, dry season, it becomes almost white, and it is often spoken of iy the farmers as "white clay." This character of material is found to an average depth of 10 or 12 inches. It is easy to till and is light and loose and readily dries a fter rains.

The subsoil, beginning at a depth of 12 inches, is a heavy, sticky red-brown clay loam, which when thoroughly dried checks into small cubes, closely resembling the stifl subsoil of the Miami gravelly loam, although it contains a much smaller percentage of small angular quartz gravel, and in many localities none whatever. When the subsoil is free from gravel it closely resembles the alluvial deposits of the Red River in Louisiana and Arkansas. The depth of the subsoil is from 2 to 5 feet. In the northern, and in some places in the central-western parts of the county, the subsoil rests directly upon the glaciated and scratched surface of the Niagara limestone. In many other places the material, at a depth of 3 or 4 feet, passes gradually into a stiff mass of clay filled with angular bowlders and pebbles and containing occasional pockets of quartz sand and well-rounded, stratified gravel. The pebbles and bowlders embedded in the mass of clay generally have sharp corners and are often scratched, especially on one side.

There is usually a small quantity of stones on the surface of the Miami clay loam, but never enough to interfere with cultivation, for where originally plentiful the bowlders have been removed. 'The percentage of small stones on the surface varies from 5 to 20 per cent. These stones are fragments of limestone and angular pieces of the metamorphic series of rocks, such as granite. gneiss, etc.

Although it has been stated that this soil is remarkably uniform, there are two areas which deserve special mention. These are a high hilly area a short distance southeast of Dayton and another somewhat similar area a few miles northwest of Dayton, in Iarrison Township. In these two localities there are several high hills, which are composed to a great extent of beds of large, rounded gravel and pockets of clean, sharp sand, overlain with a soil the exact counterpart of the soil found in the typical areas. The only difference in these areas is that at a depth of 2 feet the subsoils are underlain with gravel instead of compact clay filled with angular bowlders. The drainage conditions of these areas are the same as in the Miami gravelly loam. 
The Miami clay loam is called by various local names, which usually have some reference to the topography or the soil conditions. A common name is that of " sugar-tree land," on account of the prevalence of sugar maples in the native forests. Again, it is called "clay uplands" and "second bottom," as distinguished from the lower river bottoms proper. Frequently it is called " limestone soil." from the bed of limestone which closely underlies it. or. again. " white clay," or. if deep plowing has brought up some of the subsoils to the surface, "red clay." In the more level parts of the area, where the timber growth is largely beech, the name "beech land" is used. When these lands were first explored they were covered with a thick growth of sugar mạple, soft maple, basswood, beech, black walnut, poplar. wild cherry, white oak, blue ash, several varieties of oaks, black gum, elm. hickory, buckeye, and ironwood. There is still considerable timber standing on the liplands, which can be seen skirting the horizon in every direction.

Tobacco is the crop which seems to succeed the best on the Miami clay loam, and each year large quantities are harvested. On almost every farm will be found 3,5 , or $\$$ acres of tobacco, while many farms have from 10 to 30 acres in this crop. Tobacco grown on the uplands has a good body, good sweating properties, and is fine fibered and elastic.

The following table gives the results of a mechanical analysis of the soil and subsoil of this type:

Mechanical analysis of Miami clay loam.

\begin{tabular}{|c|c|c|c|c|c|c|c|}
\hline Description. & $\begin{array}{l}\text { Fine } \\
\text { gravel, } \\
2 \text { to } 1 \\
\text { mm. }\end{array}$ & $\begin{array}{l}\text { Coarse } \\
\text { sand, } 1 \\
\text { to } 0.5 \\
\text { mm. }\end{array}$ & $\begin{array}{l}\text { Medium } \\
\text { sand, } 0.5 \\
\text { to } 0.25 \\
\text { mm. }\end{array}$ & $\begin{array}{l}\text { Fine } \\
\text { sand. } \\
0.25 \text { to } \\
0.1 \mathrm{~mm} \text {. }\end{array}$ & $\begin{array}{l}\text { Very } \\
\text { fine } \\
\text { sand, } 0.1 \\
\text { to } 0.05 \\
\text { mm. }\end{array}$ & $\begin{array}{c}\text { Silt, } 0.05 \\
\text { to } \\
0.005 \mathrm{~mm} .\end{array}$ & $\begin{array}{l}\text { Clas, } \\
0.005 \text { to } \\
0 \mathrm{~mm} \text {. }\end{array}$ \\
\hline & Per cent. & Per cent. & Per cent. & Per cent. & Per cent. & Per cent. & Per cent. \\
\hline Soil ......... & 1.28 & 2.83 & 3.46 & 11.36 & 11.40 & 48.40 & 16.86 \\
\hline Subsoil.... & $2 . \% 2$ & 3.52 & 3.34 & 11.19 & 14.22 & 26.40 & 36.25 \\
\hline
\end{tabular}

TYPES OF LEAF.

There are four principal varieties of tobacco grown in the Miami Valley-Zimmer Spanish, Ohio seed leaf. Little Dutch, and Ohio Cuban. All of these types are grown for cigar purposes.

ZIMMER SPANISH.

In the Miami Talley the Zimmer Spanish is grown more generally than any of the other types. being in great demand at the present time as a filler for many brands of dome-tic cigars. This variety is said to be a hybrid from the native seed leaf crossed with the Cuban 
variety, and was introduced by Mr. Jacob Zimmer, from whom it takes its name. Some authorities believe it to be a modification of a variety know as the "Baltimore Cuban," the seed of this type having been distributed by the Department of Agriculture severai years ago. The plant grows about 4 feet high and has the leaves set close together on the stalk. The leaf is a little more pointed than the Cuban type, which it otherwise resembles very closely.

The Zimmer Apanish tobaco when planted on the uplands yields about 600 pounds to the acre, while on the warmer second bottom lands the yield is much greater. Although the upland tobaceo is lighter in weight, it is claimed to have the best quality and aroma. The a verage price received by the grower is 7 cents, and the highest price is seldom more than 10 cents a pound. This variety of tobacco is also grown to a limited extent in Wisconsin.

OHIO SEED LEAF.

The Ohio seed leaf is the oldest of the varieties grown in the Miami Valley, and before the introduction of the Zimmer Spanish it was grown much more generally than at present. In recent years, notwithstanding the seed leaf gives the larger yield, the Zimmer Spanish has displaced it to a considerable extent. The seed leaf is grown also in the New England States, but in that district it produces a wrapper, or binder leaf, while in Ohio it is grown almost exclusively for fillers. Because of the greater size of the plants, they are set 3 feet apart each way in the field. The leaf is very large and broad, and when ripe the edges curl over, giving it the appearance of the heavy shipping tobacco of Virginia. When well fermented the leaf makes a desirable filler and is largely used in the cheaper grades of cigars. In the past considerable quantities have been exported to Germany and France.

LITTLE DUTCH.

The Little Dutch tobacco is a sweet-scented variety grown principally around Miamisburg, although the acreage has declined in recent years. It was introduced by a Mr. Rayendorf, who brought the seed from Germany. It has a narrow leaf and a small, short growth. It is used for cigar fillers, making a cigar with an aroma resembling the Iara tobacco grown in the eastern part of Cuba. It requires great care in curing, the leaf being thin and easily damaged during the process of fermentation.

CUBAN SEED LEAF.

The Cuban seed leaf tobacco was introduced into Ohio a few years ago by some leaf dealers, who procured the seed from Florida, where 
this type of tobacco has been successfully grown for several years. Owing to the changed conditions both in soil and in climate, which destroyed the uniformity of the type, and to the methods used in its cultivation by the farmers, who were totally unacquainted with the requirements of this new rariety, the attempt was a failure, and the trade did not receive this tobacco with faror. The tobacco had most of the physical characteristics of the Cuban leaf. but it lacked the aroma which was necessary for a filler leaf. The old method of fermentation then in use did not help to bring out this quality; on the contrary, it made the leaf harsh and strong in taste, although some of the leares showed signs of merit. 


\section{GROWING OF CUBAN SEED TOBACCO.}

In the spring of 1902 the Bureau of Soils decided to see what improvements could be made in the methods of cultivating and curing tobacco grown from imported Cuban seed in the Miami Valley. Mr. George B. Massey, an expert of the Bureau of Soils, was detailed to look over the area which had been previously surveyed in the Miami Valley, to select a suitable soil, and to make other arrangements for conducting this work. A desirable soil (Miami clay loam) was located on the farms of Mr. John H. Rohrer and Mr. John A. Begard, two well-known tobacco growers of that section, and agreements were entered into with these gentlemen, under which they furnished the land, implements, and curing sheds necessary to carry on the experiments, the Bureau for its part providing the experienced labor. A crop of 6 acres was grown, fermented, and baled under the Bureau's direction, yielding 2,191 pounds of fermented tobacco. In this same season 5 acres were also planted in Zimmer Spanısh, yielding 3,700 pounds, or 748 pounds to the acre.

A second experiment was conducted during the season of 1903 to demonstrate further the possibilities of growing in Ohio a Cuban seed tobacco having the qualities demanded by the trade in a high-class cigar filler. Seven and a half acres were planted on the Miami clay loam, yielding 3,950 pounds of air-cured leaf, or 527 pounds to the acre. When fermented and baled this tobacco weighed 3,451 pounds.

In 1904 the Bureau conducted another experiment, using this time two distinct types of soil. Six acres were planted.in the upland soil (Miami clay loam), which yielded 3,056 pounds of leaf, or 509 pounds per acre, and 4 acres in the second bottom land (Miami gravelly loam), which yielded 3,082 pounds, or 770 pounds per acre. The most improved methods were used in fertilization and cultivation. Labor-saving implements were used to minimize the cost of production, and the tobacco was bulk fermented, graded, and baled according to the latest methods used where this type of tobacco is grown successfully. 
DETAILS OF THE WORK IN 1904.

The following pages detail the work connected with the production of the crops of 190t, beginning with the preparation of the seed bed and continuing through all the operations until the finished product was ready for the market.

\section{PREPARATION CF THE LAND.}

The land was plowed in the spring to a depth of $\mathrm{S}$ or 10 inches, using a two-horse plow, and as soon as the frost was out of the ground 20 loads of well-rotted stable manure to the acre were applied broadcast. This was plowed under with a two-horse plow and allowed to decay. About two weeks after this plowing the land was harrowed with a disk harrow to break up the clods and thoroughly pulverize the soil. Just before setting out the young tobacco plants the land was again harrowed with a fine-toothed harrow. which leveled off the land and left the soil in good tilth.

THE SEED BED.

In preparing the seed bed the work was commenced the preceding fall by spading the ground well and dividing it into beds 6 feet wide and about $t 0$ feet long. Each bed was surrounded by boards : inches thick and 12 inches wide, set 3 inches in the ground. These frames were filled with leaves and manure to keep out the frost during the winter season, and about the 1st of April this top dressing was raked off and the soil again spaded and well pulverized. After this a liberal application of cotton-seed meal was raked in. learing the surface of the bed smooth and loose.

About seren days before the time of planting the seed was put in apple-tree punk, made soft with warm water, and kept in a room with a temperature between $70^{\circ}$ and $75^{\circ} \mathrm{F}$. until it germinated. The sprouted seed was then mixed with cotton-seed meal and sown broadcast in the beds at the rate of 2 tablespoonfuls of seed to 100 square yards of surface. The beds were then lightly rolled to preserve the moisture and to corer the seed. it light cloth was stretched orer the bed and securely fastened to the boards on all sides. This retained the heat in the bed and protected the young plants from damage by frosts or insects.

TRANSPLA NTING.

The tobacco was transplanted from the seed bed to the field during the early part of June. The plants were set out with a mechanical planter. known as the tobacco setter. being placed 14 inche- apart in rows 3 feet apart. This machine. which rolls the ground, opens the furrow and sets and waters the plants, requires three persons to 
operate it-a man to drive and two men or boys to feed the plants into the machine. Plants set by machine are found to make earlier and better growth and to give more uniform results than when set by hand. Transplanting by this machine can be carried on and good results obtained when the weather conditions would be fatal to handset tobacco.

CULTINATION.

No plant responds more quickly to thorough cultivation than tobacco, but the plant having quite an extended system of surface roots, all cultivation should be shallow. The field should be kept clean and in good tilth, both to promote the rapid and healthful growth of the plant and to remove the hiding places afforded to insects by a growth of grass or weeds or accumulations of trash.

After the young plants had been set out a week cultivation was commenced, and thereafter the entire crop was hoed and plowed every week. In hoeing, great care was taken to break the crust that formed after each rain and to draw fresh soil up to the plant. The plowing was done with a two-horse riding cultivator, which left the plants on a slight ridge or hill, just enough to shed water in case of any very heary rains. By this method of cultivation the soil was left in a mellow and well-pulverized condition, the power of the soil to absorb and retain moisture was increased, and the root system of the plants given a larger area in which to gather food.

TOPPING AND SUCKERING.

About six weeks after transplanting the seed bud appeared. This was carefully taken out with the three top leaves, care being exercised not to injure the remaining leaves of the plant. Just when to top the plant, as well as how many leaves to take out with the bud, depends upon the climatic conditions during the growing season, the strength and vitality of the plant, and the purpose for which the leaf is being grown.

After the plants were topped suckers appeared at the junction of each leaf with the stem. These were broken off as soon as it was possible to do so without injury to the plant. Suckers will appear on all types of tobacco after being topped, and unless they are broken off the leaf will lose part of the nutritive matter which has been stored in it and deteriorate in quality.

\section{HARVESTING.}

Harresting was commenced about the middle of August, at which time the early set plants showed signs of ripeness. The time when a 
plant is ripe and ready to be cut is a matter of judgment and experience. There is a slight change in the color of the leaf. The leaf is observed to change from a rank green to a lighter shade of green, Jellow spots appear, and the leaf feels coarse and thick to the touch. It also breaks easily. especially when the dew is upon it.

Doctor Loew ${ }^{a}$ in this connection says:

The ripening of the tobacco leaf is, in other words, not a physiological but a pathological phenomenon. Br the accumulation of nicotine. oxidizing enzrms, and acids a state is finalls reached in which the normal deep green color of the chlorophrll grains gires was to a rellowish color. A "ripe" leaf contains, per 100 square centimeters, an arerage of $0.164 \mathrm{gram}$ of matter soluble in boiling water, while a roung leaf contains only 0.066, the former haring. therefore. for an equal surface about 2.5 times as much soluble organic matter as the latter. $A s$ to the total weight. a ripe leaf weighs from 1.3 to $1.5-0$ on the arerage 1.4 times as much as an equal surface of a roung leaf of the same plant. It is especially the nicotine and the protein compounds that increase in a ripe leaf, a fact of which anrone can soon conrince himself br a comparison of the reaction caused br phosphotungstic acid in the juices of ripe and unripe leares. The amount of water in ripe leares arerages, roughls, s3 per cent. and in roung leaves so per cent: that is, when compared in nearls starch-free condition, after being kept two dars in darkness. *** As to the so-called "orerripe" leaves, ther contain. like the roung leares, relatirels more water and less organic matter than the ripe leares. Br the stoppage of the functions of the chlorophrll grains. which gradualls change in the orerripe leares, new production of organic matter is prevented. while consumption still proceeds.

In harresting filler tobacco the plants are cut and not primed, as is the practice with wrappers. In cutting. the man stands orer the plant, takes hold of it with his left hand. and carefully bends it orer; with his right he cuts the stalk with a knife or hatchet just above the ground, taking care not to injure any of the leares. When sufficientle milted. it is hung upon a lath-about 12 stalks to the lathand hauled to the curing barn.

BARX CLRING.

The tobacco ras hung upon the tier poles direct from the field. and is not left upon scaffolds or racks to wilt. as is the custom among the growers of export tobacco. About 6 inches space was left between the laths hung in the top of the building to prevent a too rapid cure. or "haring down," while in the body of the barn more space was given between each lath to allow for a freer circulation of air. and in the case of damp or rainy weather to prevent pole streat, which would occur if the lath. were placed closer together.

a Phrsiological Studies of Connecticut Leaf Tobacco. Report No. 65. U. S. Dept. Agr.. 1900. 
All the ventilator's were kept shut for the first three days, during which time the tobacco undergoes its first change, viz, the turning of the leaf from a green to a bright yellow color. After this the barn was opened or closed, according to the weather conditions. No fixed rules can be given for the curing of tobacco, as the manipulation of the barn is gorerned by the conditions of the weather and the nature of the tobaceo. If the season during which the tobaceo is being cured be excessively hot and dry, it is best to close the barn tightly during the day and open it at night. During the day the tobacco will become very dry, and at night, with the ventilator's open, it will cool off and become soft and pliable.

When the tobacco is cured, with the exception of the stem or midrib, the ventilators may be left open during the day, especially on the shady side of the barn, but whenever the day is rainy or there is a strong wind blowing it is best to keep the barn closed tight to prevent damage from too much moisture or to guard against injury to the leaf by whipping. When there are frequent showers and but little sunshine, the barn should be closed, and small wood or charcoal fires. distributed throughout the barn, should be lighted for a short time each day. These fires should be continued as long as it is necessary to keep the tobacco in proper condition. When charcoal can not be obtained for fuel, wood which has as little odlor as possible should be selected. It is very important to dry out the burn without giving the tobacco any foreign odor.

The barn curing is complete when the midribs of the leaves are cured, at which time the tobacco is ready to be taken down. To get the tobacco in condition to be handled, all the ventilators should be left open the night before. In the morning the tobacco should be soft and pliable, but not wet. The barn should then be closed in order to retain the moisture.

In stripping the leaves off the stalk they are divided into three grades. The three lower leaves are called "sand leaves," the three upper leaves are called "tops," or "tips," and the leaves of the balance of the plant, which form the most desirable part of the tobacco, are called "middles." This separation is made to facilitate the handling of the leaf in the packing house, where each grade of leaf receives a different treatment in the fermentation. After stripping the leares off the stalk they are tied in hands, or bundles, containing about forty leaves each, and packed in boxes or in paper bundles for delivery to the packing house.

It is a matter of impossibility to control the moisture conditions in curing tobacco as long as the present form of curing barn is used and the prevailing method of crowding the stalks in the barn is followed. 
Ample space should be left between the laths to allow a free circulation of air, and the barn should be so constructed as to be closed tightly or thrown wide open, as the occasion demands. Where the harns are poorly constructed and the roof is leaky, it is impossible to properly manipulate the tobacco, and curing will continue to be a weak point with the Ohio growers until improvements in the barns are made. A fine crop of tobacco may be grown and harvested, and ret, on account of poor barn management, its value will in some instances be reduced 25 per cent by pole sweat. With a barn that can be tightly closed a few fires will suffice to dry the tobacco even in the dampest weather. and in this way pole sweat. mold, and damage of any kind that arises from excessive moisture can be prevented. The opening and closing of the barn requires nice discrimination. It is by allowing the tobacco to become alternately soft and dry, each to just the right degree, that the leaf is properly cured. If tobacco is allowed to dry out too quickly the color will be uneren and mottled. If, on the other hand, too long a time is taken to effect a cure the leaf will become tender. It should be the aim to manage the barn so that the tobacco will become soft and fairly dried out once in every twenty-four hours. A period of from six to eight weeks is ordinarily required to cure tobacco that is cut and hung with the stalk.

FERMENTATION.

The grower of cigar tobacco seldom ferments and packs his own tobacco, generally selling it in its green, or raw, state to the leaf dealer. The Bureau of Soils, however, desiring to gain an opinion from the trade as to the value of the leaf when produced under the very best methods from planting to packing, deemed it necessary to carry the experiment through all the various processes. Therefore. the tobacco, after barn curing, was fermented by the bulk method, sized into three grades, and packed into bales according to the Cuban style.

As received from the curing shed, the tobacco was stacked in bulks in the warehouse to ferment with its own moisture, a thermometer being placed in the bulks to determine the temperatures. The temperature was allowed to run as high as the moisture in the leaf would admit, but in no instance did it go above $120^{\circ} \mathrm{F}$. before "kasing" (adding water by artificial means). The changes in temperature of one of the bulks. which contained 3.950 pounds of tobacco. before "kasing" are shown in the following table: 
Changes in temperature of bulk during progress of fermentation.

\begin{tabular}{|c|c|c|c|c|c|c|c|}
\hline Date. & $\begin{array}{l}\text { Temper- } \\
\text { ature. }\end{array}$ & Date. & $\begin{array}{c}\text { Temper- } \\
\text { ature. }\end{array}$ & Date. & $\begin{array}{l}\text { Temper- } \\
\text { ature. }\end{array}$ & Date. & $\begin{array}{l}\text { Temper- } \\
\text { ature. }\end{array}$ \\
\hline & ${ }^{\circ} \mathrm{H}$ & & ${ }^{\circ} \mathrm{F}$ & & ${ }^{\circ} \mathrm{F}$ & & ${ }^{\circ} \mathrm{F}$ \\
\hline Nor. $21 \ldots . .$. & 55 & Dec. 9 & 103 & Dec. $2 \pi \ldots$ & 120 & Jan. 14_. & $1(0)$ \\
\hline $22 \ldots \ldots$ & 55 & $10 \ldots$ & 101 & $28 \ldots$ & 119 & $15 \ldots$ & 100 \\
\hline $23 \ldots \ldots$ & 60 & $11 \ldots \ldots$. & 100 & $29 \mu_{\ldots}$ & 78 & $16 \ldots$ & 100 \\
\hline $24 \ldots \ldots$ & 61 & $12 \ldots \ldots$ & 100 & $30 \ldots$ & 78 & $17 \ldots$ & 100 \\
\hline $25 \ldots \ldots$ & 63 & $13 \ldots \ldots$ & 100 & $31 \ldots$ & 79 & $18 \ldots$ & 100 \\
\hline $26 \ldots \ldots$ & 65 & $14 \ldots .$. & 99 & Jan. $1 \ldots$ & $8:$ & $19 \ldots$ & 101 \\
\hline $27 \ldots \ldots$ & $6 \tilde{\tau}$ & $15 a_{-}$ & 98 & $2 \ldots$ & 85 & $20 \ldots$ & 101 \\
\hline $28 \ldots \ldots$ & 69 & $16 \ldots$ & 91 & $3 \ldots$ & 86 & $21 \ldots$ & 102 \\
\hline $29 \ldots \ldots$ & $\tau_{2}$ & $17 \ldots$ & 94 & $4 \ldots$ & 86 & $22 \ldots$ & $10 \%$ \\
\hline $30 \ldots \ldots$ & 76 & $18 \ldots$ & 96 & $5 \ldots$ & 87 & $23 \ldots$ & 103 \\
\hline Dec. $1 \ldots \ldots$ & 84 & $19 \ldots$ & 102 & $6 \ldots$ & 87 & 24 & 103 \\
\hline $2 \ldots \ldots$ & 91 & $20 \ldots$ & 106 & $i \ldots$ & 89 & 25. & 101 \\
\hline $3 \ldots \ldots$ & 98 & $21 \ldots$ & 110 & $8 \ldots$ & 89 & $26 \ldots$ & 99 \\
\hline $4 \ldots \ldots$ & 101 & $22 \ldots$ & 112 & $9 \ldots$ & 92 & $2 \pi_{-}$ & 96 \\
\hline $5 \ldots \ldots$ & 104 & $23 \ldots$ & 115 & $10 \ldots$ & 94 & $28 \ldots$ & 90 \\
\hline $6 \ldots \ldots$ & 105 & $24 \ldots \ldots$ & 118 & $11 \ldots$ & 96 & $29 \ldots$ & 88 \\
\hline $7 \ldots \ldots$ & 106 & $25 \ldots \ldots$ & 119 & $12 \ldots$ & 99 & $30 \ldots$ & 85 \\
\hline $8 \ldots .$. & 105 & $26 \ldots$ & 120 & $13 \ldots$ & 100 & & \\
\hline
\end{tabular}

a Bulk turned.

The moisture originally contained in the tobacco had nearly all evaporated during this fermentation, but owing to the heavy nature of the leaf it was deemed advisable to ferment it again. During the early part of February the bulk was taken down, each hand of tobacco was dipped in water to add sufficient moisture to the leaf to renew active fermentation, and a new bulk built. Within the next six days the temperature had reached $121^{\circ} \mathrm{F}$., when the tobacco was again taken down, each hand shaken out, and then rebulked. In this bulk the highest temperature was reached on February 25, when the thermometer read $120^{\circ} \mathrm{F}$., and from that date to February 29 the temperature gradually fell a few degrees each day, indicating that the action of fermentation was growing less. The tobacco was rebulked again on March 1. After this turning the temperature did not rise above $109^{\circ} \mathrm{F}$., and on March 31 it fell to $98^{\circ} \mathrm{F}$. The bulk of tobacco was then taken down, sized, graded, and rebulked to age, remaining thereafter at an average temperature of $102^{\circ} \mathrm{F}$. 
The changes in temperature of the bulk after kasing are given in the following table:

Changes in temperature of bulk.

\begin{tabular}{|c|c|c|c|c|c|c|c|}
\hline Date. & $\begin{array}{l}\text { Temper- } \\
\text { ature. }\end{array}$ & Date. & $\begin{array}{l}\text { Temper- } \\
\text { ature. }\end{array}$ & Date. & $\begin{array}{l}\text { Temper- } \\
\text { ature. }\end{array}$ & Date. & $\begin{array}{l}\text { Temper- } \\
\text { ature. }\end{array}$ \\
\hline & ${ }^{\circ} F$ & & ${ }^{\circ} F$. & & ${ }^{\circ} \mathrm{F}$. & & ${ }^{\circ} \mathrm{F}$. \\
\hline Feb. $13 \ldots$ & 75 & Feb. 25..... & 120 & Mar. 8.. & 100 & Mar.22. & 109 \\
\hline 14 & 85 & $26 \ldots$ & 120 & 9 & 100 & 23 & 109 \\
\hline $15 \ldots$ & 97 & $2 \pi \ldots$. & 119 & $11 a_{-}$. & 73 & 24 & 106 \\
\hline $16 \ldots$ & 110 & $28 \ldots \ldots$ & 117 & $12 \ldots$ & $\%$ & 25. & 106 \\
\hline $17 \ldots \ldots$ & 115 & $29 \ldots$ & $11 \%$ & $13 .$. & $\because$ & $26 \ldots$ & 106 \\
\hline $18 \ldots$ & 120 & Mar. $1 a_{-.}$ & $8 \%$ & $14 .$. & $\tau 9$ & $2 \tilde{\imath} \ldots$ & 105 \\
\hline $19 \ldots$ & 121 & - $2 \ldots \ldots$ & 91 & $15 \ldots$ & 86 & $28 \ldots$ & 105 \\
\hline $20 a_{\ldots} \ldots$ & 91 & 3. & 93 & $16 \ldots$ & . 93 & $29 \ldots$ & 100 \\
\hline $21 \ldots$ & 95 & $4 \ldots . .$. & 99 & $1 \tau_{\ldots} .$. & 100 & $30 \ldots$ & 100 \\
\hline $22 \ldots$ & 111 & $5 \ldots . .$. & 101 & $18 \ldots$ & 105 & $31 \ldots$ & 98 \\
\hline $23 \ldots \ldots$ & 115 & $6 \ldots \ldots$ & 101 & $19 \ldots$ & 107 & & \\
\hline $24 \ldots \ldots$ & 120 & ז...... & 100 & $21 \ldots$ & 108 & & \\
\hline
\end{tabular}

a Bulk turned.

This method of fermentation remores the danger of injury to the tobacco by black rot or other fungus, and minimizes the chances for unerenness in color or flavor due to excessive or deficient local fermentations. During the process of rebulking, the tobacco is thoroughly shaken out and aired, and all objectionable gases are given an opportunity to pass off. That such an elimination takes place is readily proved by a noticeable odor which fills the room during the first turning of the bulk. This odor, which is decidedly disagreeable at first, is less objectionable during the second turning. During the third and fourth turnings the tobacco has attained a mellow, aromatic odor, and when this stage is reached there is no need for fear of further damage. The tobacco can remain indefinitely in bulk to age, or it can be packed in bales to undergo the same process. This final aging or ripening of filler tobacco is necessary to put it in the proper condition for the manufacturer.

BALING.

Tying the tobacco in carrots and packing it in bales was the last manipulation in preparing it for market. Four hands of tobacco were tied together with bast, and 80 of these carrots were packed in a bale made of palm bark imported from Cuba, over which was placed a covering of burlap. The bales weighed about 112 pounds and were stacked five high in a room of arerage temperature to season or age. The care of the tobacco after being baled depends largely upon the condition in which it is packed. If it is thoroughly cured and well dried out it should be stored in a place where it will remain as near dormant as possible, as further fermentation is unnec- 
essary. If the tobaceo is packed in high "kase" (with considerable moisture) fermentation will continue, especially during the summer months. The position of the bales should be changed every week, and they should occasionally be opened for examination, and, if necessary, stood on end to cool off and stop fermentation.

COST OF PRODUCTION.

A careful account was kept of all expenditures connected with the production and finishing of the crop of Cuban seed tobacco grown in the experiment of 190t. The two tables following give the cost of each operation on the basis of 1 pound as the unit.

Cost of growing Cuban seed tobacco.

\begin{tabular}{|c|c|}
\hline Operation. & $\begin{array}{l}\text { Cost per } \\
\text { pound. }\end{array}$ \\
\hline & Cents. \\
\hline Preparing land, sowing, and weeding seed bed... & 1.00 \\
\hline Pulling plants and transplanting & 1.25 \\
\hline Plowing, five times & 1.50 \\
\hline Ḣoeing, three times & 1.00 \\
\hline Topping and suckering .................... & 1.50 \\
\hline Harresting & 2.25 \\
\hline Poisoning & .25 \\
\hline Taking down from poles and stripping & 1.75 \\
\hline Total ..... & 10.50 \\
\hline
\end{tabular}

Cost of fermenting and packing Cuban seed tobacco.

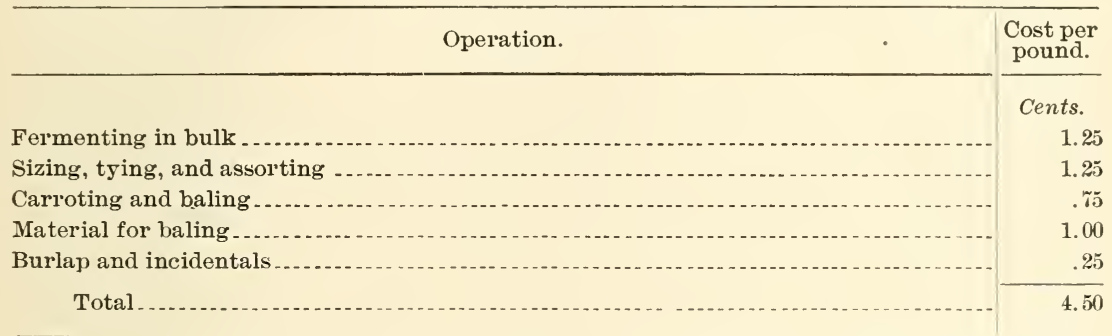

The total cost of the crop of $T_{2}$ acres, including cultivation, harresting, and warehouse work, was $\$ 517.65$, or 15 cents per pound on the basis of the fermented leaf. It cost nearly half as much to ferment and pack the crop as it did to produce it to the time it was ready for the warehouse.

The total yield on $7 \frac{1}{2}$ acres of Cuban seed tobacco was 3.950 pounds, or an average of 527 pounds of cured tobacco per acre. The total yield after fermentation was 3,451 pounds, or 460 pounds per acre, showing a total loss of weight during fermentation of 499 pounds, or 67 pounds per acre-a shrinkage of 13 per cent from the time the tobacco was taken from the poles to the time it was packed in the bale. 
The following table shows the weights of the different grades of tobacco produced:

I'roportion and reight of different grades of Cuban seed tobaco in crop of 19').

\begin{tabular}{|c|c|c|}
\hline Grade. & Weight. & $\begin{array}{c}\text { Propor - } \\
\text { tion. }\end{array}$ \\
\hline & Pounds. & Percent. \\
\hline 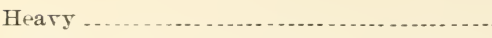 & 2,401 & 69.0 \\
\hline Light & 538 & 15.1 \\
\hline Broken & 5l2 & 14.1 \\
\hline Total .................. & 3,451 & \\
\hline
\end{tabular}

From this table it will be seen that 69 per cent of the crop graded as heary filler, 15 per cent as light filler, and 14 per cent as broken and trashy leares.

SALE OF TOBACCO GROWN IN 1902 AND 1903 EXPERIMIENTS.

In the fall of 1904 samples of the Zimmer Spanish and the Ohio Cuban seed, grown in 1902 and 1903, were placed on the market. The sale of the 1902 crop, which included both Zimmer Spanish and Cuban seed, was intrusted to Mr. H. G. Tetterlein, of Philadelphia, and of the Ohio Cuban, grown in 1903, to Mr. John Rohrer, of Germantown. Ohio. The employment of persons directly connected with the trade was deemed adrisable both to relieve the Bureau of the details of making the sales and to insure the protection of the growers. The Department of Agriculture had no interest in the receipts from the sales of these tobaccos, but was interested solely in the results as indicating the judgment of the trade as to the value of the leaf for filler purposes. The proceeds of sales, less the broker's commission, were turned over to the owners of the several crops.

In December, 1904. Mr. Vetterlein sold to Messrs. Dohan \& Tait. of Philadelphia, 20 half cases of the Zimmer Spanish. weighing 3,196 pounds, at $16 \frac{1}{2}$ cents per pound. As will be seen from a letter from this firm, quoted on a following page, the quality of the leaf was perfectly satisfactory.

The 1902 Ohio Cuban has not been sold, the trade pronouncing the leaf a little too heary. This is not due. howerer, to the rariety of tobacco, as all types of tobacco grown that year in the Miami Valley, including the Zimmer Spanish. were not up to the standard of quality. owing to the unfarorable climatic conditions during the growing season.

In the winter of 1904-5 Mr. Rohrer submitted to the trade samples of the Ohio Cuban grown in 1903. In response he received from The Samuel Hirsch Company, of Cincinnati, Ohio, an offer of $3 \check{\text { cents a }}$ pound for the entire crop, which was accepted. 
The 21 bales weighed about 3,178 pounds net, and at 35 cents per pound, less :3 per cent for cash, the amount received was $\$ 1.078 .9:$, or a return for the finished product of $\$ 1+3.85$ per acre.

Is a result of the experiments of the last three years, there will be grown during 190.) about 35 acres of Cuban seed tobacco. This tobaceo will be grown by the farmers of the Miami Valley under Govarmment supervision, and already a firm has declared its intention to purchase the tobacco at 15 cents per pound, green woight, wherever the grower obtains a cents per pound for his Zimmer Spanish, a proportionate increase or decrease being made in the price if the Zimmer type brings more or less than the price stated.

The following letters have been received from persons and firms who have handled the tobacco grown in the experimental crops of 1902 and 1903 :

[From John H. Rohrer, Germantown, Ohio.]

I have received a letter from the Sam T. Hirsch Company, Cincinnati, Ohio, the firm to whom I sold the 1903 Ohio Cuban, in which they state that the first 2 bales they received from the Department warehouse had been manufactured and had given perfect satisfaction, and although the remainder of the crop was not to have been shipped until April 15 , they wished me at once to ship 2 more bales, as they are in need of the tobacco.

I am perfectly satisfied that with favorable climatic conditions and thorough and systematic fertilization and cultivation, we can grow here in the Miami Valley a satisfactory grade of filler tobacco from Cuban seed, which, I believe, will return a good profit to the grower. I draw these conclusions after haring paid close attention to the crops grown during the past three years under Mr. Massey's direction, and also after a close examination of the leaf after fermentation.

The introduction of bulk fermentation of our native tobaccos I consider to be the most practical piece of work your Department has yet done. in Ohio. It has not only sared thousands of dollars to the packers, which otherwise they would have lost in damaged tobacco, but it has enabled us to place an article ef better quality on the market and within a shorter period of time. It is my opinion that in the course of a year or two every pound of Ohio cigar tobacco will be fermented by the bulk method of fermentation that your Department has introduced with so much success.

\section{[From The Samuel Hirsch Company, Cincinnati, Ohio.]}

In regard to your favor of the 11th, we wish to say that we find the tobacco in question (Ohio Cuban seed) rery satisfactory. We consider it a rery lesirable filler and are very much pleased with our purchase.

[From Dohan \& Taitt, Philadelphia, Pa.]

Yours of March 1 at hand, and we beg to state that the Zimmer Spenish grown by your Bureau, and purchased by us, we consider exceedingly fine, though a rather heary-bodied tobacco. We have not tested your Texas tobacco thoroughly, having only smoked a cigar or two, from which we could not form a fair idea of the tobacco. We regret that we can not give you our opinion of the latter, but the general appearance of the tobacco is excellent. 


\title{
INTRODUCTION OF BULK FERMENTATION IN OHIO.
}

\author{
DESCRIPTION OF VARIOCS METHODS.
}

Prior to the introduction by the Bureau of Soils of the bulk method of fermentation into the cigar-leaf districts of Ohio two methods of fermentation were in use, viz. the natural sweat and the force sweat. Both methods had disadrantages, and great loss was rearly sustained by the packers, owing to damage of various kinds traceable directly to the inability to control the process of fermentation under the hitor-miss systems employed.

In the natural sweat process the leaf is packed under pressure into ases holding from 300 to 400 pounds. Then the cases are filled and closed they are stored for eight or ten months without being given any attention whaterer. The idea is that the tobacco will warm up at the beginning of spring weather and continue to ferment during the summer months. In the early part of the succeeding fall the tobacco is examined and sampled for the first time after being packed. The examination not infrequently reveals the fact that a large proportion of the tobacco has been damaged or, as the packers say. " has dereloped black rot." The cases then are opened and the damaged hands or leares picked out and the sound portion repacked. This involves a great deal of trouble and expense aside from the direct loss in the damaged tobacco.

It is claimed by some packers that the damage occurs soon after the tobacco is packed. while lying in a chilled condition. and that this can be prevented by forced sweating. Many packers, therefore, prepare a room in their warehouse where, either by means of steam or stores. a high temperature can be steadily maintained. As soon as a case of tobacco is packed it is put into this room and when the room is filled it is closed and the temperature kept from $110^{\circ} \mathrm{F}$. to $112^{\circ} \mathrm{F}$. This sweating process is continued for thirty or forty days, at the end of which time the tobacco is taken out and allowed to cool and dry. While there is some show of curing in the center of the case. the tobacco on the top and at the bottom and sides of the case is not cured. but has become iry. and there is ordinarily as much damaged leaf as where the natural sweat method is followed.

In the bulk method of fermentation the tobacco is moistened if need be. piled on a platform. and covered with blankets. In the bulk is inserted an electrical thermometer. by means of which the 
(hanges in temperature, indicative of the progress of fermentation, are known to the packer, and the tobaceo can be so manipulated as to keep the fermentation within the limit of safety. It is this matter of absolute control of the process that marks the superiority of the bulk method over the methods of natural or forced sweating.

To support the bulk a platform should be made, o feet wide and irom 12 to 14 feet long, raised about 4 inches from the floor of the sweat room. At the ends of this platform are placed footboards 6 feet wide and 7 feet high. Such a platform will hold from 5,000 to 6,000 pounds of tobacco. After covering the platform and headboards with paper, the bulking is begun by laying the two outer rows, placing the heads of the tobaceo even with the edges of the platform and allowing the tips to point to the center. Then another row is begun on each side, allowing the heads to rest two-thirds of the length of the leaf from the butts of the first row, keeping the tips pointing to the center. A third row is made on each side in the same manner. This will make six rows across the width of the platform, or sufficient to cover the floor. The second tier is laid in the same manner, and this process is continued until the bulk has reached a height of 6 or 7 feet, or until 5,000 or 6,000 pounds of tobacco have been bulked. When the bulk is completed the top is covered with ordinary cotton blankets, over which are placed rubber blankets.

The tobacco is allowed to stay in bulk from ten to twelve days, the actual time being governed by the character of the leaf and condition of the tobacco when placed in bulk. Ordinarily the temperature increases about $6^{\circ} \mathrm{F}$. every twenty-four hours. When the temperature has reached a certain degree, which varies with different types of leaf, the tobacco is taken off the bulk, well shaken out, and rebulked, building the new bulk as the old one is taken down.

To rebulk tobacco the handler should proceed as follows: Take off the first two layers from the bulk and place them in cases. Then take the tobacco from the old bulk and lay the foundation of the new one, building up the tiers until half the old bulk is removed. Place the two layers that were set aside on the new bulk and refill the cases with two more layers from the old bulk, and set these aside until the remainder of the old bulk has been placed on the new. Place the two cases of tobacco on the new bulk and cover it with blankets as before. In this way what was the inside of the old bulk has become the outside of the new, and what was the outside of the old bulk has become the inside of the new bulk. In this way every part of the tobacco will recerve the same amount of fermentation. When the rebulking is completed the tobaceo is allowed to stand until the temperature rises to a maximum limit and starts to fall. As soon as the temperature declines sufficiently-the exact point varies with the 
different types-the tobacco is taken out of the bulk and packed in cases.

DETAILS OF FERMENTATION OF LEAF OF DIFFERENT TYPES.

There are differences in the character of the Zimmer Spanish, Ohio seed leaf, and Little Dutch tobaccos which necessitate modifications in the processes of fermenting the several types. Though these modifications are slight, they are of vital importance, and ha ve been made the subject of careful investigation during the three years that the work has been carried on in Ohio. Perhaps the most important question has been that of artificially moistening the leaf before bulking, and it has been established-that only the Zimmer Spanish and Ohio seed leaf varieties can be moistened, the same quantity of water added to the Iittle Dutch tobacco ruining the leaf. Other important questions determined are the number of rebulkings necessary, the length of time required to complete the fermentation, the temperatures at which the tobacco should be turned, etc. These questions, as appertaining to the different types of tobacco, will be considered in detail.

As the greater part of the Ohio cigar filler is Zimmer Spanish. the fermentation of this type is of more general interest to the Ohio grower and packer. 'This tobacco as received from the grower does not contain sufficient moisture to carry it through the fermentation, and, being a rather heavy-bodied leaf, it requires a higher temperature to complete the process than is necessary in case of the other Ohio filler types. To obtain an active ferment of this leaf it is necessary to add moisture. This is done by dipping the hands in water and allowing the leaf thoroughly to absorb the moisture before placing it in the bulk. This the leaf will do in about forty-eight hours. It is seldom found necessary in fermenting Zimmer Spanish to turn the bulk more than once, as the two heatings put the leaf in perfect condition for packing in cases where it undergoes the process of aging.

Some packers ferment their tobacco before sizing and assorting it, and in this case the tobacco is taken from the bulk after the temperature has reached the maximum and declined to a point within $105^{\circ}$ to $120^{\circ} \mathrm{F}$., at which stage the leaf can be sized and sorted without hecoming too dry to pack. If the tobacco has been sized and sorted before being bulked it is generally left until the temperature has cooled off to $100^{\circ}$ or $105^{\circ} \mathrm{F}$. The tobacco has then just enough moisture in it to pack well.

The average cost of bulk fermenting Zimmer Spanish tobacco, which includes "kasing," bulking, and packing in cases, is 90 cents per 100 pounds. The following table gives the temperature of a bulk of Zimmer Spanish: 
Changes in temperature of a bulk of Zimmer spanish tobaceo.

\begin{tabular}{|c|c|c|c|c|c|c|c|}
\hline Date. & $\begin{array}{l}\text { Temper- } \\
\text { ature. }\end{array}$ & Date. & $\begin{array}{c}\text { Temper- } \\
\text { ature. }\end{array}$ & Dato. & $\begin{array}{l}\text { Teimper- } \\
\text { ature. }\end{array}$ & Date. & $\begin{array}{l}\text { Temper- } \\
\text { ature. }\end{array}$ \\
\hline & ${ }^{\circ} F$ & & $\circ \mathrm{H}$. & & ${ }^{\circ} F$. & & $F$ \\
\hline Apr. $20 \ldots . .$. & 84 & Apr. $28 \ldots . .$. & 134 & May 6... ... & 111 & May $14 \ldots . .$. & 138 \\
\hline $21 \ldots$ & 90 & $2 !$ & 139 & $7 \ldots$ & 118 & 15 & 135 \\
\hline $22 \ldots$ & 96 & $30 a \ldots$ & 139 & $8 \ldots \ldots$ & 124 & $16 \ldots$ & 133 \\
\hline $23 . \ldots$ & 104 & May 1..... & 86 & $9 \ldots \ldots$ & 128 & $17 \ldots . .$. & 129 \\
\hline $24 \ldots \ldots$ & 112 & 2 & 91 & $10 \ldots \ldots$ & 129 & $18 \ldots \ldots$ & 128 \\
\hline $25 \ldots . . .$. & 117 & $3 \ldots \ldots$ & 96 & $11 \ldots$ & 133 & $19 \ldots \ldots$ & 125 \\
\hline $26 \ldots \ldots$ & 124 & $4 \ldots \ldots$ & 99 & $12 \ldots \ldots$ & 137 & $20 b \ldots$ & 119 \\
\hline $2 \tau_{\ldots} \ldots$ & 131 & $5 \ldots \ldots$ & 105 & $13 \ldots \ldots$ & 138 & $21 \ldots \ldots$ & $11 \%$ \\
\hline
\end{tabular}

"Bulk turned.

${ }^{b}$ Bulk taken up, assorted, sized, and packed.

The Ohio seed leaf usually has to be "kased." The same method of moistening the tobacco is followed as with the Zimmer Spanish, and the leaf is allowed forty-eight hours to absorb the moisture before being placed in bulk. Owing to the character of this leaf the temperature of the bulk is not allowed to go higher than $130^{\circ} \mathrm{F}$. It is seldom necessary for this type to go through more than two heatings unless it has been too heavily "kased," when a third heating will be necessary. After the second heat the temperature of the bulk will decline, and when it reaches $107^{\circ} \mathrm{F}$. the tobacco should be taken down and packed in cases to age.

The cost of bulk fermenting seed leaf tobacco, including " kasing," bulking, and packing in cases, is 65 cents per 100 pounds. The following table gives the temperature of a bulk of Ohio seed leaf tobacco:

Changes in temperature of a bulk of Ohio seed leaf tobacco.

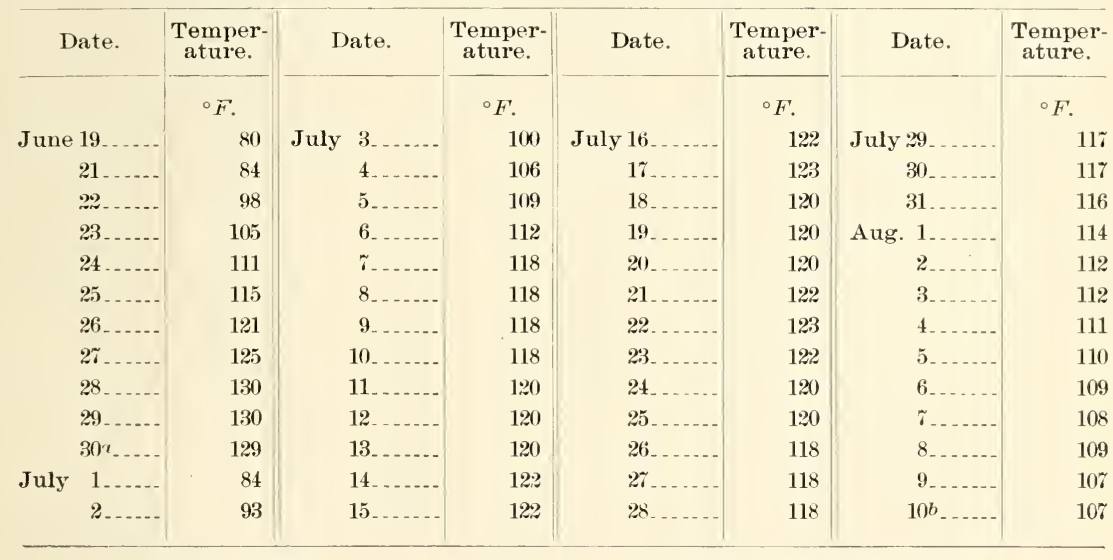

a Bulk turned.

${ }^{\circ}$ Bulk taken down and packed.

In bulk fermenting Little Dutch tobacco great care and judgment have to be exercised, as this type is much more likely to be damaged during the process than either the Zimmer Spanish or Ohio seed leaf. 
This variety does not require such a high temperature to ferment it, but it is allowed to remain in the bulk at a lower temperature for a greater length of time. The addition of water is very seldom necessary, and, owing to the relatively small quantity of moisture in the leaf, the bulk, after the first turning, seldom reaches a temperature of more than $128^{\circ} \mathrm{F}$. Like the other varieties of Ohio cigar-filler leaf, it is rarely found necessary to turn the bulk more than once, two heatings being enough to prevent the development of mold or black rot. When the temperature of the bulk has declined to about $90^{\circ}$ or $100^{\circ} \mathrm{F}$. the tobacco may be taken down and packed. The leaf at this temperature has been found to contain just enough moisture to pack well.

The arerage cost of fermenting Little Dutch tobacco, including bulking and packing. is t5 cents per 100 pounds. The following table gives the temperature of a bulk of Little Dutch tobacco:

Changes in temperature of a bulk of Little Dutch tobacco.

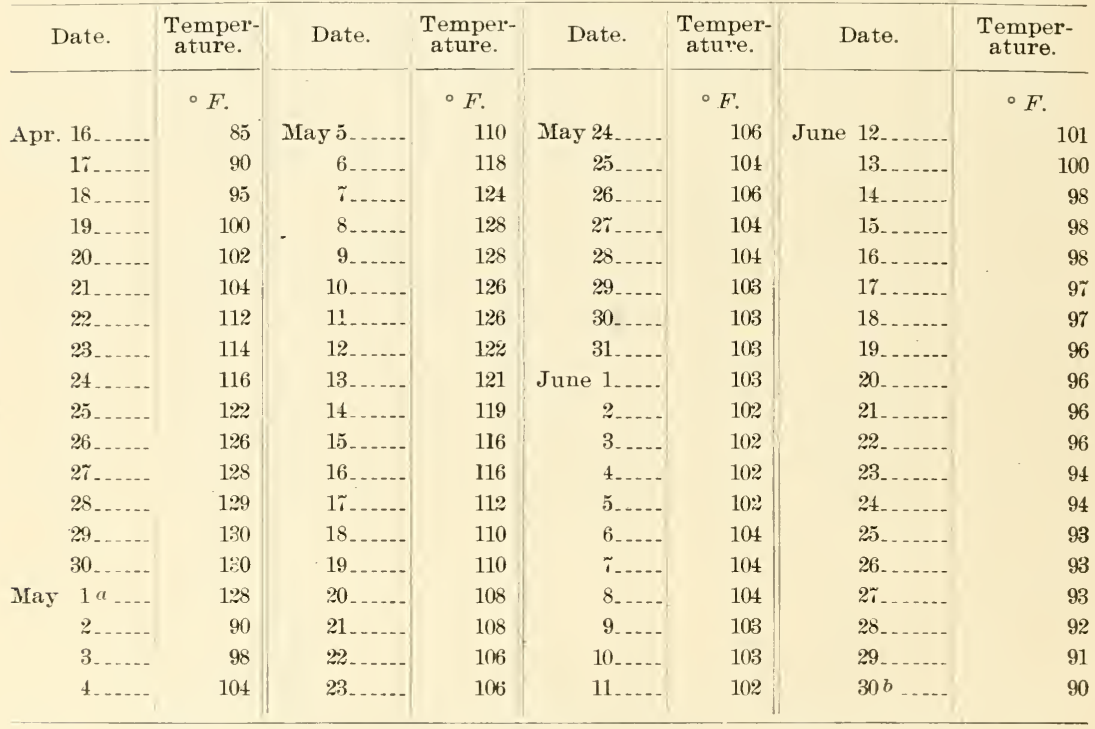

a Bulk turned.

${ }^{b}$ Bulk taken down and packed in cases.

As was to be expected, some trouble was experienced during the earlier stages of the investigations in Ohio. In one of the first bulks of Zimmer Spanish tobacco fermented black rot had begun to develop. but by decreasing the size of the bulk and placing a layer of trash of a thickness of 8 inches under and over the good tobacco the spread of the fungus was prevented. In some cases, also, white mold made its appearance. Experiments soon showed that by forcing the temperature up to $140^{\circ} \mathrm{F}$. the spores of this fungus could be rendered innocuous, and thereafter this source of danger was under complete control. 
The indications of both these dangerous conditions are discoverable, if they exist at all, on the first turning of the bulk, and steps can at once be taken to prevent the spread of the trouble. Under the old methods of fermentation the conditions would not be known until the tobacco is sampled, when much of the tobacco would be irretrievably ruined.

\section{RELATIVE COST OF DIFFERENT METHODS OF FERMENTATION.}

It has been urged by some packers that it is cheaper to case ferment tobacco than it is to ferment it in bulk, which is probably true where the tobacco is given but four or five days' preliminary fermenting in the case and then finally packed in cases under pressure and allowed to dry out in the sweat room for a few weeks. Such manipulation, however, is at best a compromise, and tobacco handled in this way is not thoroughly fermented. If tobacco be given two packings before it is finally cased, as must be done to feiment the leaf thoroughly, it has been demonstrated that the cost is even greater than the cost of bulk fermenting.

\section{COOPERATIVE WORK DURING THREE SEASONS.}

During the spring of 1902 the Bureau of Soils began experiments in the fermentation of the native Ohio tobacco, believing that by using the method of bulk fermentation already outlined the damage arising from mold and black rot could be eliminated. The plans of the Bureau for fermenting filler tobacco were explained to several local leaf dealers, and arrangements were entered into with these gentlemen to ferment part of their tobacco according to the proposed method. They agreed to provide the necessary warehouse room and tobacco for conducting the experiments, while the Bureau of Soils provided the experienced labor. Accordingly, bulks were built in five different warehouses. The following table gives the names of the packers cooperating with the Department, the location of the warehouses where the experiments were carried on, and the number of pounds of tobacco fermented:

Bulk fermented tobacco, 1902.

\begin{tabular}{|c|c|c|}
\hline Packer. & Location of warehouse. & $\begin{array}{c}\text { Tobacco } \\
\text { fermented }\end{array}$ \\
\hline & \multirow{7}{*}{$\begin{array}{l}\text { Germantown } \\
\text { Camden } \\
\text { Gratis } \\
\text { Dayton } \\
\text { Germantown }\end{array}$} & Pounds. \\
\hline Joseph Endress ........... & & 360,000 \\
\hline Four Tobacco Company .... & & 162,000 \\
\hline Young Brother's & & 72,000 \\
\hline Miami Leaf Tobacco Company & & 21,600 \\
\hline J.H. Rohrer & & 39,600 \\
\hline Total & & $655,200)$ \\
\hline
\end{tabular}


This tobacco was mostly Zimmer Spanish, grown the year before, and had become dry and hard, which made it necessary to add water to get the leaf in the proper condition to cause fermentation. After being dipped the tobacco was packed loosely in cases and allowed to remain about twenty-four hours, by which time it had thoroughly taken up the water. making the leaves soft and pliable: It was then placed in bulks, containing from 6,000 to 8,000 pounds. The tobacco was not packed tightly, but simply piled loose, only hand pressure being used, and the temperature of the room was kept at about $75^{\circ} \mathrm{F}$. The tobacco was well fermented at the end of sixty days. On taking the bulk down and packing the tobacco into cases. no sign of damage of any kind was found, and the leaf was thoroughly fermented its entire length.

These packers were so well pleased with the results obtained that the Bureau of Soils was asked to continue the experiment on a larger scale the following year. The new process had created such an interest among the tobacco packers of the Miami Valley that not only did those firms cooperating with the Bureau the prerious year ask for further assistance, but requests were receired from other packers for the cooperation of the Bureau in fermenting their tobacco.

During the season of 1903 the Bureau supervised the fermentation of 4.212.000 pounds of tobacco, consisting of the Zimmer Spanish. the Ohio seed leaf, and the Little Dutch varieties. The work was performed in cooperation with 10 packers in the Miami Valley. The following table gives the details of this season's work:

Bulk fermented tobacco, 1903.

\begin{tabular}{|c|c|c|c|}
\hline Variety of Tobacco. & Packer. & Location. & $\begin{array}{c}\text { Tobacco } \\
\text { fermented. }\end{array}$ \\
\hline Zimmer Spanish & 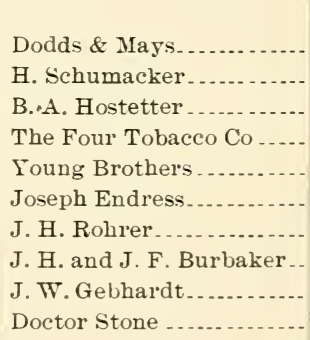 & $\begin{array}{l}\text { Miamisburg } \\
\text { Dayton } \\
\text { West Manchester } \\
\text { Camden } \\
\text { Gratis } \\
\text { Germantown } \\
\text { West Alexander } \\
\text { Miamisburg } \\
\text { Union City }\end{array}$ & $\begin{array}{r}\text { Pounds. } \\
\qquad 900,000 \\
396,000 \\
720,000 \\
162,000 \\
90,000 \\
108,000 \\
21,600 \\
360,000 \\
14,400 \\
144,000\end{array}$ \\
\hline Total & & & $2,916,(00$ \\
\hline Ohio seed leaf. & $\begin{array}{l}\text { B. A. Hostetter . } \\
\text { H. Schumacker } \\
\text { J. H. Rohrer. }\end{array}$ & $\begin{array}{l}\text { Richmond, Ind } \\
\text { Dayton } \\
\text { Germantown }\end{array}$ & $\begin{array}{l}648,000 \\
216,000 \\
144,000\end{array}$ \\
\hline Total & & & $1,008,000$ \\
\hline Little Dutch.... & $\begin{array}{l}\text { B. A. Hostetter } \\
\text { H. Schumacker } \\
\text { Dodds \& Mays....................... }\end{array}$ & $\begin{array}{l}\text { Richmond, Ind } \\
\text { Dayton } \\
\text { Miamisburg }\end{array}$ & $\begin{array}{r}252,000 \\
16,200 \\
19,800\end{array}$ \\
\hline & & & 288,0001 \\
\hline
\end{tabular}


During the season of 1904 the Burean still further extended its work in bulk fermentation. Most of the packers who cooperated with the Bureau during the seasons of 1902 and 1903 placed larger quantities under the Bureals charge for fermentation, while other firms, seeing the advantage to be derived from bulk fermentation, arlopted the method. During the season of 1904, 10.208,000 pounds of the varjous types of Ohio tobacco were fermented. The table below gives the details of the work in the same manner as has been done for the two seasons preceding.

Bulk fermented tobacco, 190\%.

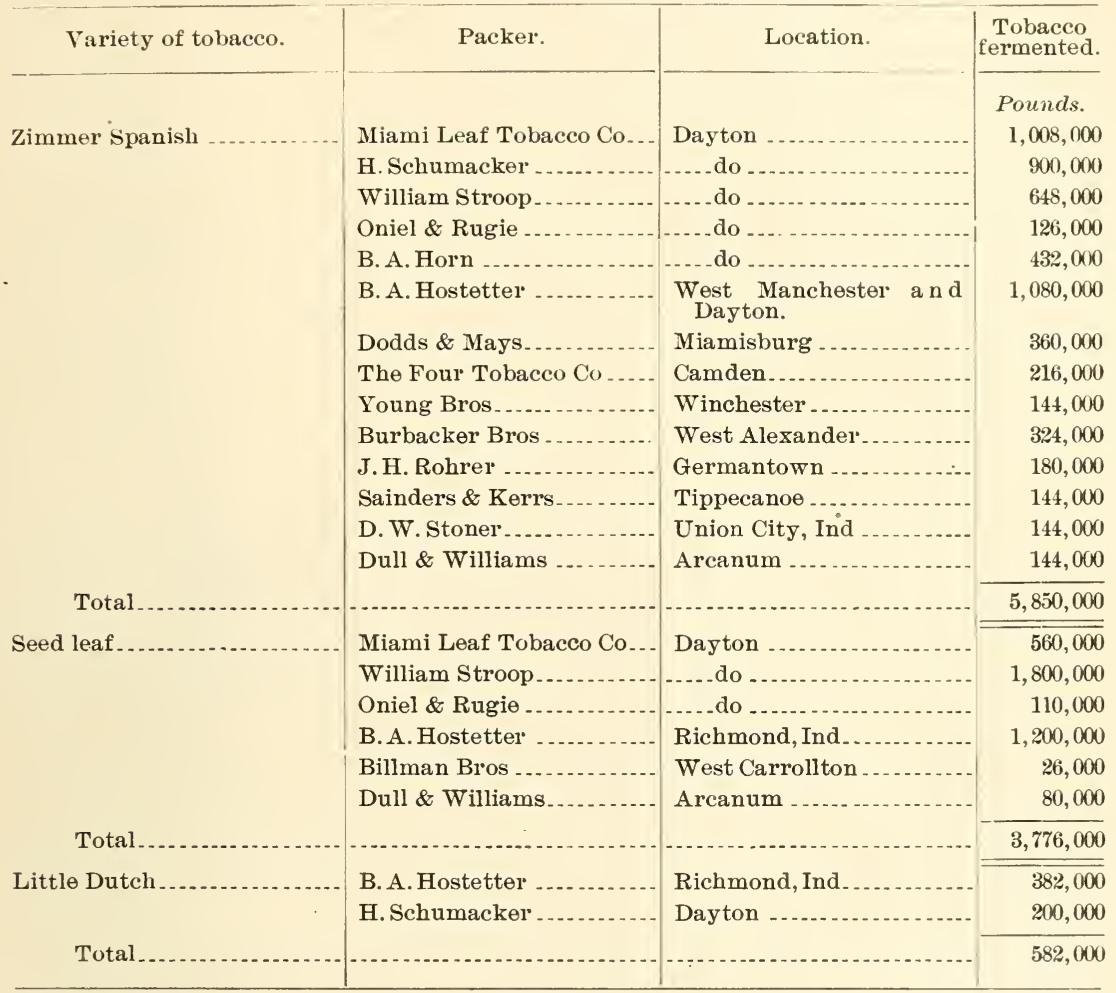


The following table shows the number of pounds of native Ohio tobacco bulk fermented under the direct supervision of the Bureau during the three last seasons:

I'otal quantities of different types of ohio filler tobacco bulk fermented during 1902,1903 , and 1904.

\begin{tabular}{|c|c|c|c|c|}
\hline Year. & $\begin{array}{l}\text { Zimmer } \\
\text { Spanish. }\end{array}$ & Seed leaf. & $\begin{array}{l}\text { Little } \\
\text { Dutch. }\end{array}$ & Total. \\
\hline 1902. & $\begin{array}{r}\text { Pounds. } \\
655,200\end{array}$ & Pounds. & Pounds. & $\begin{array}{l}\text { Pounds. } \\
60.55,200\end{array}$ \\
\hline $1903 \ldots \ldots$ & $2,916,000$ & $1,008,000$ & 288,000 & $4,212,(x) 0$ \\
\hline 1904 & $5,850,000$ & $3, \pi 6,000$ & 582,000 & $10,208,000$ \\
\hline Total, three years...... & $9,421,200$ & $4,784,000$ & $8 \% 0,000$ & $15,0 \pi 5,200$ \\
\hline
\end{tabular}

advance information shows that $20,000,000$ pounds of tobacco will be bulk fermented in Ohio during the season of 1905 - a gain of about 33 per cent over the total shown for 1904 .

The following table, showing the entire crop of domestic filler tobacco for 1901 and the imports of Cuban tobacco, will be of interest: Comparative statement of quantities and value of domestic and imported cigarfiller tobacco.

\begin{tabular}{|c|c|c|}
\hline - Leaf. & Production. & Value. \\
\hline Ohio ....... & $\begin{array}{l}\text { Pounds. } \\
35,654,314\end{array}$ & $33,832,839$ \\
\hline Pennsylvania ...................... & $1 \tilde{i}, 614,380$ & $2,113,225$ \\
\hline Other domestic filler ............... & $17,666, \tilde{5} 31$ & $1,971,584$ \\
\hline Total domestic filler..... & $\tau 0,935,225$ & $7,918,148$ \\
\hline Imported Cuban, 1901 crop & $18,554,775$ & $16,212,773$ \\
\hline
\end{tabular}

In the above statement the production of domestic tobacco is on the basis of fermented leaf, 20 per cent having been deducted from the total production for shrinkage in fermentation and loss in handling.

In the case of Ohio the necessary allowance for types other than cigar-filler tobacco has been made. Two cents per pound has been added to the value of the domestic tobacco to provide for the expense of fermentation, thus putting the Cuban imports and the domestic filler on the same basis.

It will be seen from these figures that the Cuban imports. which are only one-fourth as large in quantity, represent in the aggregate a value two and one-third times as great as the value of the domestic product. It would seem that there is opportunity here for the growers and packers of tobacco in our filler States to improve the quality of their product and increase their profits. 


\section{LET'TERS FROM THE TRAIDE.}

The following letter's have been received by the Bureau from packer's that have changed their methods of fermentation to that prescribed by this Bureau:

\section{[From Ilanna Brothers, Dayton, Ohio.]}

In response to your inquiry in reference to the process of resweating Ohio tobacco in bulk, we would say that, with a very few exceptions, all the packers, dealers, and manufilcturers of Ohio have adopted the bulk sweating method, which in itself is evidence of the popularity and success of the method.

Being in a position (as brokers) to come in contact with a majority of our dealer's in the Miami Valley and with jobbers and large manufacturers of our leaf tobacco, and hearing the comments of different firms and individuals, we feel safe in stating that it is the universal opinion that the bulk sweating process is the most modern. most economical, and most satisfactory means to gain desired results.

We certainly are convinced that the Department has acted very wisely in establishing an experimental station in our valley, so ably conducted by your - representative, Mr. G. B. Massey, at Germantown, Ohio, to whom we cheerfully recommend the trade for any information on the foregoing subject, and whom we regard as very courteous and obliging. We are pleased to learn that he is to remain with us another eighteen months.

\section{[From William Stroop, Dayton, Ohio.]}

I heartily approve of bulk sweating our cigar-leaf tobaccos, as I have been using this process of finishing my tobaccos for a number of years, and am pleased to see that the Government has taken up this matter and has been successful in inducing other handlers of leaf tobacco to see the advantages of the bulk-sweating process.

I am very familiar with the work you are doing at your station at Germantown, Ohio, and think your operations are very commendable and beneficial.

[From W. K. Gresh \& Son, Norristown, Pa.]

For the past two years we have followed the system of bulk sweating. as introduced by Mr. George B. Massey, of your Bureau, at our packing house in Dayton. Ohio.

We find to our great satisfaction that this mode of curing tobacco eliminates all danger of damage, yields a more thoroughly fermented product, and is less expensive than case sweating. We also find that cigars made up from such bulk-sweated tobacco have better burning qualities and a better aroma than from case-sweated stock. Therefore we can not but appreciate and heartily approve the endeavors of your Bureau to introduce improved methods in the growing as well as in the handling of cigall-leaf tobacco.

\section{[From the Miami Leaf Tobacco Company, Daston, Ohio.]}

We desire to testify to the earnest work that has been done by your expert in this State. Mr. George Ir. Massey, along the lines designed by you in your effort to better the processes of growing and handling leaf tobacco. 
We know that Mr. Massey has done hard and earnest work, and while from the nature of the business the results arrived at may be indeterminate, still we know they have been of considerable influence on the trade.

Of the 1903 crop, mostly through Mr. Massey's efforts, we would estimate that fully 50 per cent was bulk sweated. There is no question whatever but that bulk sweating brings out all the best qualities of the tobacco and is the safest way to sweat it, although from a strictly commercial standpoint there are times when the expense would prohibit it on anything except the very highest-priced tobaccos.

We ourselves bulk sweated our entire crop of 1903 , with splendid results as to quality, and had almost no loss whatever in damaged leaf. 


